\title{
AN ASSESSMENT OF AGRICULTURAL ENTERPRISES OWNED BY WOMEN FARMERS IN IKPOBA-OKHA LOCAL GOVERNMENT, EDO STATE, NIGERIA
}

\author{
C. O. EDEOGHON AND M. T. AJAYI
}

(Received 4 November, 2008; Revision Accepted 5 May, 2009)

\begin{abstract}
The study assessed the agricultural enterprises owned by women farmers in Ikpoba-Okha Local Government, Edo State, Nigeria. Using a structured questionnaire, data were collected from 60 randomly selected women farmers. Findings show that majority of the respondents were within the ages of $26-50$ years $(70 \%), 85 \%$ were married, $31.7 \%$ did not have any form of formal education while $46.7 \%$ had up to primary school education. The study revealed that $41.7 \%$ of the respondents had $4-6$ children while $21.7 \%$ had $7-9$ children. Findings also showed that majority $(98.3 \%)$ of the respondents were engaged in cassava production enterprise while $55 \%$ were engaged in poultry production. Cassava was perceived to be the most profitable enterprise followed by poultry. Respondents also perceived these enterprises to have assisted them in taking care of children schools fees and improve their nutritional status thereby improving their standard of living. The result indicated that all the respondents had contact with extension agents in form of farm visits (twice weekly) and extension demonstration (every 6 months). However, the major constraints faced by the women farmers were poor produce prices (Mean, $\bar{x}=2.98$ ), lack of credit (Mean $\bar{x}=2.97$ ) and poor market outlet (Mean, $\bar{x}=2.77$ ) for their produce. Respondents' age, $(r=0.412, p<0.05)$, number of children $r=0,373$, $p<0.05)$ and business experience $(r=0.435, p<0.05)$ had significant and positive relationship with respondents' derived benefits from their enterprises It was therefore recommended that women association should be formed and organized into cooperatives so as to increase their access to extension, credit, input and marketing services.
\end{abstract}

KEY WORDS: Assessment, agricultural enterprises, owned, women farmers.

\section{INTRODUCTION}

Women are the backbone of the agricultural sector accounting for $70 \%$ of agricultural labour and being responsible for the bulk of agricultural production food processing and utilization in sub-Saharan Africa (Kabeer, 1994, Banmeke and Olowu, 2005). Sustainable agriculture and effective rural development cannot be pursued without explicit recognition of sustainable contribution of women (FAO, 1998). Rural women play a significant role in household food security such as agriculture production, providing economic access to food for household and ensuring nutritional standards for household members.

World Bank analysis of gender and investment in the agricultural sector concludes that in countries where half or more of all farming is done by women, neglect of the needs of female farmers in rural development programmes reduces total agricultural output by as much as $20 \%$ (Black den, and BhanuChiatra, 1999). Augusta (2006) addressed agricultural enterprise as knowledge skill or labour applied to growing or raising plants or animals, harvesting plants or growing or obtaining plants or animal by-products. Also, forestry and aquaculture, production, storing, packaging or marketing are involved. Major agricultural enterprises are crop production, livestock production and food processing.

In crop production, women are involved in almost all aspects with exceptions of land preparation and other mechanized and capital intensive activities. (FAO, 1995) however contended that women play a key role in seed selection and hence they have the responsibility for quality and quantity of crop produced. Women are largely responsible for food crop production while men are mainly responsible for cash crops such as rubber.

Women's role in livestock production is even greater, as they are often responsible for all aspects of animal husbandry, with the exception of herding and marketing. Hence they feed, water and care for small ruminants, rabbits and poultry. They also breed and select animals (FAO, 1995).

Processing such as converting cassava into garri, starch and fufu; guinea corn into kunu drink, soya bean into soya milk, maize into corn flour and akamu, oil palm into palm oil, native soap and vegetable processing have been mainly handled by women. However, despite their contribution to global food security, women farmers are frequently underestimated and overlooked in developing strategies (FAO, 1999b). Olawaoye (1989) also indicated that despite the significant role of women in agricultural production, extension services are directed to men farmers and only few women farmers are reached. For this reason, women find it more difficult than men to gain access to valuable resources (FAO, 1999b). Therefore, targeting women farmers will bring high returns because access to extension service make

C. O. Edeoghon, Department of Agricultural Economics and Extension Services, University of Benin, Benin City, Nigeria

M. T. Ajayi, Department of Agricultural Economics and Extension Services, University of Benin, Benin City, Nigeria 
women better informed and hence prepares them to become active partners in development activities (Verma, 2001). It is in this light that this study conceived to answer to the following questions: (a) what agricultural enterprises are women most involved in? (b) what are the roles of extension service to the women in agricultural production? (c) what are the problems women farmers face in their agricultural enterprises? The general objective of this study was to identify the types of agricultural enterprises owned by women farmers in Ikpoba-Okha local government area of Edo state, Nigeria. The specific objectives were to:

- $\quad$ examine the socio-economic characteristics of women farmers in the study area;

identify the types of agricultural enterprises women are involved in

determine the women's perception of the profitability of their enterprises;

assess the respondents' contact with agricultural extension service

identify constraints faced by women farmers in running their agricultural enterprises.

Hypothesis:

- There is no significant difference between the socio-economic characteristics of women farmers and benefits derived from enterprise production.

\section{METHODOLOGY}

The study was carried out in Ikpoba-Okha local government area (LGA) of Edo State, Nigeria.. The local government area is bounded by Orhionwon LGA and in the North by Egor and Uhunmwunde LGAs. In the south, it shares boundary with Koko in Delta State. Various agricultural practices in the local government include crop production, lumbering, fishery, art and craft including wood works, brass making and general merchandise.

A population of 320 women farmers that registered with Agricultural Development Programme (ADP) was the sampling frame of this study. The women farmers were grouped by ADP into eight (8) with each group made up of 40 women farmers. Simple random sampling technique was used to select 3 groups out of the 8 groups and from each of these 3 groups sampled, 20 women farmers were randomly selected. The 3 groups selected of women farmers were located in 3 villages: Obaretin, Uhie and Iyanomo. A total sample of 60 women farmers were therefore interviewed using a structured questionnaire.
The instrument was designed to include Likerttype scales with a four-point scale (1= no response, $2=$ not profitable, $3=$ moderately profitable and $4=$ highly profitable used to describe respondents' perception of profitability of their enterprises and a three point scale (1 =not severe, 2 = severe, $3=$ very severe, used to describe respondents' constraints in their enterprises.

Descriptive statistics such as frequency counts, percentage, means and standard deviation were used to analyze the data collected while correlation analysis was used to test the hypothesis.

\section{RESULTS AND DISCUSSION}

\section{Socio-economic characteristics of respondents:}

Table1shows that majority of the respondents were within the ages of $26-50$ years $(70 \%)$. Only $10 \%$ of the respondents were within the ages of 60 and above. This indicates that the women farmers are more active in farming in their youthful age as Oyatoye (1991) confirms that age affects the productivity of the farmers. Among the respondents, $85 \%$ were married while $15 \%$ were windows. Technical Centre for Agricultural and Rural Cooperation (CTA) (1999) stated that femaleheaded households are under capitalized by as much as $50 \%$ of the total value of farming equipment compared to male headed households.

Educational qualification of respondents indicated that $31.7 \%$ did not have any form of formal education and $46.7 \%$ had up to primary school education. The result also revealed that $41.7 \%$ of the respondents had 4-6 children while $21.7 \%$ had $7-9$ children. It was also observed that $96.7 \%$ of the respondents had farming as their primary occupation while $56.7 \%$ of the respondents were involved in some non-farm activities as their secondary occupation such as trading and sewing. This is in line with Oyatoye (1991) who found out that those who regard themselves as traders deal mainly in farm produce.

It is surprising that none of the respondents belong to any organization. This is because this result is at variance to the findings of FAO (2003a) which reported that membership of cooperatives, farmers' organization, trade unions and other organizations represent one of the best ways for rural men and women to gain access to resources, opportunities and decision making. Women are however frequently deterred from joining because membership is often restricted to recognized land owners or heads of households. Farming experience of respondents as Table 1 shows that $28.3 \%$ have been into agricultural business for 6 10 years while $23.3 \%$ have been into the business for more than 20 years. 
Table 1: Socio-economic characteristics of respondents $(n=60)$.

\begin{tabular}{|c|c|c|}
\hline Variable & Frequency & Percentage (\%) \\
\hline \multicolumn{3}{|l|}{ Age (years): } \\
\hline $26-40$ & 24 & 40.0 \\
\hline $41-50$ & 18 & 30.0 \\
\hline $51-60$ & 12 & 20.0 \\
\hline Above 60 & 6 & 10.0 \\
\hline \multicolumn{3}{|l|}{ Marital Status: } \\
\hline Married & 51 & 85.0 \\
\hline Widowed & 9 & 15.0 \\
\hline \multicolumn{3}{|l|}{ Educational Qualification: } \\
\hline None & 19 & 31.7 \\
\hline Did not Complete Primary School & 1 & 1.7 \\
\hline Completed Primary School & 28 & 46.7 \\
\hline Did not complete Secondary School & 5 & 8.3 \\
\hline Completed Secondary School & 5 & 8.3 \\
\hline Above Secondary School & 2 & 3.3 \\
\hline \multicolumn{3}{|l|}{ Number of Children: } \\
\hline None & 1 & 1.7 \\
\hline $1-3$ & 12 & 20.7 \\
\hline $4-6$ & 25 & 41.7 \\
\hline $7-9$ & 13 & 21.7 \\
\hline Above 9 & 9 & 15.0 \\
\hline \multicolumn{3}{|l|}{ Major Occupation: } \\
\hline Farming & 58 & 96.7 \\
\hline Trading & 1 & 1.7 \\
\hline Hand work & 1 & 1.7 \\
\hline \multicolumn{3}{|l|}{ Non-Farm activity: } \\
\hline Sewing & 1 & 1.7 \\
\hline Trading & 33 & 55.0 \\
\hline No Response & 26 & 43.3 \\
\hline \multicolumn{3}{|l|}{ Membership of Organization } \\
\hline Yes & - & - \\
\hline No & 60 & 100 \\
\hline \multicolumn{3}{|l|}{ Business Experience (Years) } \\
\hline $1-5$ & 15 & 25.0 \\
\hline $6-10$ & 17 & 28.0 \\
\hline $11-15$ & 6 & 10.0 \\
\hline $16-20$ & 8 & 13.3 \\
\hline Above 20 & 14 & 23.3 \\
\hline
\end{tabular}

Source: Field Survey, 2007

Types of agricultural enterprises owned by respondents:

Table 2 shows the types of agricultural enterprises owned by the women. The result reveals that as regards crop enterprise, majority $(98.3 \%)$ of the respondents are engaged in cassava production enterprise while for livestock enterprise, majority (55\%) are engaged in poultry production. This result is not unexpected because of the publicity given to cassava production and processing currently in Nigeria. The result also supports the finding of Agbamu and Esegbue (2007) in Delta State, Nigeria that majority of cassava farmers in Isoko North Local Government area of Delta State were women.

Table 2: Types of agricultural enterprises owned by respondents

\begin{tabular}{lll}
\hline Agricultural Enterprises & Frequency & Percentage (\%) \\
\hline Crop Enterprise & & \\
Cassava & 59 & 98.3 \\
Yam & 34 & 56.7 \\
Vegetable Production & 29 & 48.3 \\
Maize & 29 & 48.3 \\
Plantation & 18 & 30.0 \\
Fruit & 6 & 10.0 \\
Banana & 1 & 1.7 \\
Livestock Enterprise & & \\
Poultry & 33 & 55.0 \\
Goat & 13 & 21.7 \\
Sheep & 6 & 10.0 \\
Rabbitery & 1 & 1.7 \\
\hline
\end{tabular}

Multiple Responses

Source: Field Survey, 2007. 
Respondents' perception of the profitability of agricultural enterprises:

Table 3 shows that $50 \%$ of the women farmers perceived cassava to be the most profitable crop enterprise followed by poultry in which $41.7 \%$ perceived to be also profitable. This must have been the major reason why many of the respondents were involved in cassava and poultry enterprises.

Table 3: Respondents' perception of the profitability of agricultural enterprises

\begin{tabular}{|c|c|c|c|c|c|c|c|c|}
\hline \multirow[t]{2}{*}{ Enterprise } & \multicolumn{2}{|c|}{ High Profitability } & \multicolumn{2}{|c|}{ Moderately Profitable } & \multicolumn{2}{|c|}{ Not Profitable } & \multicolumn{2}{|c|}{ No Response } \\
\hline & Frequency & $\%$ & Frequency & $\%$ & Frequency & $\%$ & Frequency & $\%$ \\
\hline Cassava & 30 & 50.0 & 22 & 36.7 & 6 & 10.0 & 2 & 3.3 \\
\hline Poultry & 6 & 10.0 & 25 & 41.7 & 1 & 1.7 & 28 & 46.7 \\
\hline Goat & 5 & 8.3 & 8 & 13.3 & - & - & 4.7 & 78.3 \\
\hline Plantain & 4 & 6.7 & 16 & 26.7 & - & - & 40 & 66.7 \\
\hline $\begin{array}{l}\text { Vegetable } \\
\text { Production }\end{array}$ & 2 & 3.3 & 22 & 36.7 & 3 & 5.0 & 33 & 55.0 \\
\hline Yam & 2 & 3.3 & 32 & 53.3 & - & - & 26 & 43.3 \\
\hline Banana & 1 & 1.7 & 1 & 1.7 & - & - & 58 & 96.7 \\
\hline Sheep & 1 & 1.7 & 6 & 10.0 & - & - & 53 & 88.3 \\
\hline Fruit & - & - & 5 & 8.3 & - & - & 55 & 91.7 \\
\hline Oil Palm & - & - & - & - & - & - & 60 & 100.0 \\
\hline Maize & - & - & 29 & 48.3 & 1 & 1.7 & 30 & 50.0 \\
\hline Melon & - & - & 28 & 46.7 & - & - & 32 & 53.3 \\
\hline Fishery & - & - & - & - & - & - & 60 & 100.0 \\
\hline Piggery & - & - & - & - & - & - & 60 & 100.0 \\
\hline Rabbitery & - & - & - & - & - & - & 60 & 100.0 \\
\hline Grass & - & - & - & - & - & - & 60 & 100.0 \\
\hline Cutter & & & & & & & & \\
\hline Others & - & - & - & - & - & - & 60 & 100.0 \\
\hline
\end{tabular}

\section{Respondents' Derived Benefits from enterprises:}

Respondents' derived benefits from running their enterprises are shown in Table 4. The result shows that the most important benefits for respondents include better schooling for children (98.3\%), ability to afford 3 meals per day $(98.3 \%)$, improved food consumption/ nutrition $(91.7 \%)$ and better medical treatment. These results support FAO (1999b) which recognized the empowerment of women as key to raising levels of nutrition, improving the production and distribution of agricultural products and enhancing the living conditions of rural population.

Table 4: Respondents' derived benefits from agricultural enterprises

\begin{tabular}{lll}
\hline Benefits & Frequency & Percentage \% \\
\hline Better Schooling for Children & 59 & 98.3 \\
Ability to afford 3 meals a day & 59 & 98.3 \\
Improved Food Consumption/Nutrition & 55 & 91.7 \\
Better Medical Treatment & 51 & 85.0 \\
Better clothing & 49 & 81.7 \\
Better Housing & 25 & 41.7 \\
Furnished House & 11 & 18.3 \\
Built a House & 4 & 6.7 \\
Bought Electronics & 3 & 5.0 \\
Bought Car & 1 & 1.7 \\
Installed Borehole & - & - \\
\hline Multiple Responses & \multicolumn{2}{l}{}
\end{tabular}

Forms and frequency of respondents' contact with extension agents:

Results in Table 5 show that all the respondents $(100 \%)$ have had contact with the Agricultural Development Programme (ADP) in form of farm visits (twice weekly) and extension demonstration (every 6 months).
The respondents also claimed to have received support services in forms of provision of planting materials and better farming techniques. This result indicates that farmers will be informed about new technologies and plant varieties and this would enhance their production.

Table 5: Forms and frequency of respondents' contact with extension agents

\begin{tabular}{|c|c|c|c|c|c|c|c|c|c|c|c|c|c|}
\hline \multirow[t]{2}{*}{ Form of Contact } & \multicolumn{2}{|c|}{ Twice Weekly } & \multicolumn{2}{|c|}{ Once a Month } & \multicolumn{2}{|c|}{$\begin{array}{l}\text { Every } \\
\text { Months }\end{array}$} & \multirow[t]{2}{*}{3} & \multicolumn{2}{|c|}{$\begin{array}{l}\text { Every } \\
\text { months }\end{array}$} & \multicolumn{2}{|c|}{ Once a Year } & \multicolumn{2}{|c|}{ Not at All } \\
\hline & Freq & $\%$ & Freq & $\%$ & Freq & $\%$ & & Freq & $\%$ & Freq & $\%$ & Freq & $\%$ \\
\hline Field days & - & - & - & - & - & - & & - & - & - & - & 60 & 100 \\
\hline Farm Visits & 60 & 100 & - & - & - & - & & - & - & - & - & - & - \\
\hline Training & - & - & - & - & - & - & & - & - & - & - & 60 & 100 \\
\hline $\begin{array}{l}\text { Extension } \\
\text { demonstrations }\end{array}$ & - & - & - & - & - & - & & 60 & 100 & - & - & - & - \\
\hline
\end{tabular}


Constraints faced by respondents in their enterprises

Table 6 shows constraints faced by respondents in their enterprises. The major constraints faced by respondents were poor produce prices (98.3\%), lack of credit $(96.7 \%)$ and poor market outlet for produce
$(85.0 \%)$ The result on lack of credit is similar to the observation of Baudi and deBruijen (1993) in southern Africa that married women that have knowledge, ability and time to engage in large scale business activities face difficulties in obtaining loans.

Table 6: Constraints faced by respondents face in running their agricultural enterprises.

\begin{tabular}{|c|c|c|c|c|c|c|c|c|}
\hline & \multicolumn{2}{|c|}{ Very Severe } & \multicolumn{2}{|c|}{ Severe } & \multicolumn{2}{|c|}{ Not Severe } & \multicolumn{2}{|l|}{ Total } \\
\hline & Freq & $\%$ & Freq & $\%$ & Freq & $\%$ & Mean & Std. Dev. \\
\hline Produce Price & 59 & 98.3 & 1 & 1.7 & - & - & 2.98 & 0.13 \\
\hline Lack of Finance/ Credit & 58 & 96.7 & 2 & 3.3 & - & - & 2.97 & 0.18 \\
\hline Market Outlet for Produce & 51 & 85.0 & 4 & 6.7 & 5 & 8.3 & 2.77 & 0.59 \\
\hline Pest & 23 & 38.3 & 33 & 55.0 & 4 & 6.7 & 2.32 & 0.60 \\
\hline Disease & 14 & 23.3 & 34 & 56.7 & 12 & 20.0 & 2.03 & 0.66 \\
\hline Transportation & 15 & 25.0 & 32 & 53.3 & 13 & 21.7 & 2.03 & 0.69 \\
\hline Environmental Factors & 3 & 5.0 & 4 & 6.7 & 53 & 88.3 & 1.17 & 0.49 \\
\hline $\begin{array}{l}\text { Attitude of Financial bodies towards } \\
\text { women farmers }\end{array}$ & - & - & - & - & 60 & 100.0 & 1.00 & - \\
\hline $\begin{array}{l}\text { Extension Agents' Attitude towards } \\
\text { Women }\end{array}$ & - & - & - & - & 60 & 100.0 & 1.00 & - \\
\hline
\end{tabular}

Source: Field Survey, 2007

Relationship between respondents'socio-economic characteristics and derived benefits from enterprises:

Table 7 shows that the age $(r=0.412, p<0.05)$, number of children $(r=0.373, p<0.05)$, business experience $(r=0.435, p<0.05)$ had significant and positive relationship with respondents' derived benefits from their enterprises. As for age, this means the older farmers derive more benefits from enterprise production. For number of children, positive correlation means that households with larger number of children derive more benefits from enterprise production which may be that children assist their parents in the farming activities.

As for business experience, positive correlation indicates that longer farming experience increases benefits derived from enterprise.

Table 7: Relationship between respondents' socio-economic characteristics and benefits derived from enterprises

\begin{tabular}{lll}
\hline Variables & Correlation Coefficient & P-level \\
\hline Age & $0.412^{*}$ & 0.001 \\
Educational Qualification & 0.140 & 0.086 \\
Number of Children & $0.373^{*}$ & 0.004 \\
Number of Crop Enterprise & 0.180 & 0.085 \\
Total livestock Enterprise & 0.159 & 0.123 \\
Farm Size (Hectare) & 0.111 & 0.076 \\
Business Experience & $0.435^{\star}$ & 0.001 \\
\hline
\end{tabular}

* Significant at the $p \leq 0.05$ level

Source: Field Survey, 2007

\section{CONCLUSION AND RECOMMENDATIONS}

The study has established that women farmers owned agricultural enterprises just like their male counterparts especially cassava and poultry enterprises. The study also established that the enterprises have assisted women farmers to alleviate poverty but they need assistance in pricing of their produce, access to credit and marketing of their produce. Based on the findings: the following recommendations are made:

1 Women association in the village should be formed and organized into cooperatives so as to increase their access to extension, credit, input and marketing services.

2 There is a need for extension service to organize training activities for the women so as to further empower them.

3 Government and individuals should make available better transportation services in the rural areas for easy evacuation of goods from the farm gate to the market.

\section{REFERENCES}

Agbamu, J. U. and Esegbue, S., 2007. Farmers' perception of improved and local cassava cultivars in Isoko North Local Government Area of Delta State, Nigeria. Global Approaches to Extension Practice, 3(2): 1-8.

Augusta, M., 2006. Commerce and Trade: Building and Development.

http://janus.state.me.us/legis/statutes/10/title10s ec963-A.html viewed November 26th, 2007.

Banmeke, T. O .A. and Olowu, T. A., 2005. Accessibility of Women Farmers to Agricultural Information in South Western Nigeria, South African Journal of Agricultural Extension, 34 (2): 237- 246

Baudi, S. A. and deBruijen, G. A., 1993. Gender, small scale industry and development policy: Intermediate Technology Publications, UK. 
Blackden, M. and Bhanu-Chitra., 1999. Gender, Growth and Poverty Reduction. Technical paper no.428, World Bank, Washington, DC, USA.

Food and Agriculture Organization, FAO., 1995. Improving the relevance and effectiveness of agricultural extension activities for women farmers. An Andre Mayer research study, FAO, Rome,

Italy. http://www.fao.org/docerp/v4805SE/v4805e03.h tm SP113 - 22017; Viewed 19 April, 2007.

Food and Agriculture Organization, FAO., 1998. Gender roles in peanut sector for household food security, FAO, Rome, Italy. http://www.fao.org/docerp/005/ac794e/AC794E. htm\#TOC; Viewed 19 April, 2007.

Food and Agriculture Organization, FAO., 1999b. Gender and food security, agriculture; Women as users, managers and preservers of biodiversity, FAO, Rome, Italy. http://www.fao.org/gender/en/agri-e.htm; Viewed 19 April, 2007.

Food and Agriculture Organization, FAO., 2003a. Gender and Development Plan of Action: Agricultural Support System, FAO, Rome, Italy. http://www.fao.org/docerp/005/Y3969e/Y3969e0 5.htm; Viewed 19 April, 2007.

International Fund for Agricultural Development, IFAD., 1999. Syria: Women's role in agriculture, Rome, October,

http://ifad.org/english/operations/pn/syn/index.htm. Viewed 15 August, 2007.

Kabeer, N., 1994. Reversed Realities, Gender Hierarchies in Development Thought. Paper presented at the seminar on 'The Economic Role of Women in Rural and Agricultural Development: the promotion of income generating activities', Athens, Greece, $18-22$, October.

Olayemi, J. K., 1980. Food crop production by small farmers in Nigeria. Pp 18 - 33, In: Olayide, S.O; Eweka, J.A; Bello-Osagie, V.E; (Editors), Nigerian Small Farmers: Problems and Prospects in Integrated Rural Development, Centre for Agricultural Rural Development (CARD), University of Ibadan, Nigeria.

Olawoye, J. E., 1989. Difficulties of rural women in securing resources for agricultural production. The case studies from Oyo State, Nigeria. Rural Development in Nigeria, 3 (2): 77 -81.

Oyatoye, E. T. O., 1991. Increasing Productivity in Nigeria: A discussion of findings from a survey on roles of women in Nigerian Agriculture. Pp 401 - 411, In: Umeh, P.O.C; Usman, G.A; Anjorin, S.A; Oluleye, O.B; (Editors), (Proceedings of the First National Conference on Productivity, organized by the National Productivity Centre), Macmillan Nigerian Publishers Limited.

Technical Centre for Agricultural and Rural Cooperation, CTA, 1999. The Role of Women in Agricultural and Rural Development: promoting income generating activities, a summary report of a seminar, Athens, Greece, 18 - 22 October.

Verma, O. S., 2001. Gender Sensitization- Women in Agricultural Development. .Journal of Extension Systems, 17(2): $83-93$. 